\title{
INDIRECT CONTACT HEAT RECOVERY WITH SOLIDIFICATION IN THERMOCHEMICAL HYDROGEN PRODUCTION
}

\author{
S. Ghandehariun ${ }^{1}$, G. F. Naterer ${ }^{2}$, M. A. Rosen ${ }^{3}$, Z. Wang ${ }^{3}$ \\ ${ }^{1}$ Faculty of Engineering, University of Alberta \\ Edmonton, AB, T6G 2G8, Canada \\ ${ }^{2}$ Faculty of Engineering and Applied Science, Memorial University of Newfoundland \\ St. John's, NL, A1B 3X5, Canada \\ ${ }^{3}$ Faculty of Engineering and Applied Science, University of Ontario Institute of Technology \\ Oshawa, ON, L1H 7K4, Canada \\ samane@ualberta.ca, gnaterer@mun.ca, marc.rosen@uoit.ca, zhaolin.wang@uoit.ca
}

\begin{abstract}
An analysis is presented for the heat transfer from molten salt in the copper-chlorine thermochemical cycle for hydrogen production. For this cycle to become economical relative to other existing or developing technologies, effective heat recovery is very important. Heat recovery processes are investigated from molten $\mathrm{CuCl}$ (a product of the copper oxychloride decomposition process in the $\mathrm{Cu}-\mathrm{Cl}$ cycle). Recovering heat from molten $\mathrm{CuCl}$ at $500^{\circ} \mathrm{C}$ is challenging due to its phase change from liquid to solid. Based on a previous examination of different options for this heat recovery (including atomization with steam generation, casting/extrusion, drum flaker and a rotary spinning atomizer), the casting/extrusion method was deemed advantageous. Hence that process is considered here, with a counter-current air flow as a coolant. Predicted results for axial growth of the solid layer and variations of the coolant and wall temperatures are presented and discussed. The effects of the inner tube diameter and air mass flow rate are also investigated.
\end{abstract}

Keywords: hydrogen production, thermochemical water decomposition, heat recovery, indirect contact

\section{INTRODUCTION}

Hydrogen has been shown to be a viable transportation fuel, which is versatile, efficient to utilize, and safe [1]. However, there exist various engineering and economic factors that limit the extensive use of hydrogen as a fuel. Hydrogen can be produced from various substances such as water, hydrocarbons, biomass, hydrogen sulfide, and others. Hydrogen production processes can be driven by thermal, electrical, photonic, or biochemical energy which can be obtained from fossil, nuclear, 
renewable or other energy resources [2-8]. Table 1 summarizes the main hydrogen production methods. Currently, hydrogen is mainly produced via steam methane reforming (SMR) which causes significant greenhouse gas emissions [9, 10]. Therefore, developing alternative sustainable methods of hydrogen production is required to reduce greenhouse gas emissions and accelerate the transition to a low-carbon future.

Water electrolysis is a mature technology for hydrogen production in which electricity is used to split water into hydrogen and oxygen. Electrical energy can be obtained from renewable or nonrenewable resources [11-16]. There are three main types of electrolyzers available: alkaline, polymer electrolyte membrane (PEM), and high temperature solid oxide electrolyzer (SOE). Typical specifications of various electrolyzers are listed in Table 2. An energy and exergy analysis was conducted by $\mathrm{Ni}$ et al. [15] to investigate the thermodynamic and electrochemical characteristics of hydrogen production by a PEM electrolyzer plant. Their model showed that the thermal energy demand increases at higher temperatures while the electrical energy decreases. A hydrogen production system based on Solid Oxide Electrolysis Cells (SOECs) was modeled and compared to the performance of a more mature system based on PEM technology [14]. The results showed that the modeled SOEC hydrogen generation system can compete with the PEM electrolyzer, achieving better performance than the low-temperature system at hydrogen production rates higher than 18.3 $\mathrm{g} / \mathrm{h}$ (corresponding to $0.25 \mathrm{~A} / \mathrm{cm}^{2}$ ) and showing an energy efficiency up to $14 \%$ higher than the PEM system at $1 \mathrm{~A} / \mathrm{cm}^{2}$.

Thermochemical water splitting, using various heat sources such as nuclear energy, solar energy, or geothermal energy, is an alternative cleaner process for hydrogen production. The overall efficiencies of some thermochemical cycles are potentially significantly higher than those for electrolysis [17]. Several thermochemical cycles for hydrogen production have been developed over the past four decades [18-27]. Among various cycles, the copper-chlorine cycle is one of the most promising cycles, in part because it requires heat at a maximum temperature of less than $500^{\circ} \mathrm{C}$ [28]. The copper-chlorine (Cu-Cl) cycle decomposes water into hydrogen and oxygen, through 
intermediate copper chloride compounds, in a closed loop that recycles all chemicals continuously. The reaction steps of the cycle are shown in Table 3.

The overall efficiency of the cycle can be improved by recovering heat within the cycle and minimizing the net heat supply to the cycle. If all released heat is recycled internally, the efficiency of the cycle increases significantly [29, 30]. It was shown that for a five-step Cu-Cl cycle, the overall efficiency of the cycle can be improved from $37.2 \%$ with no heat recovery to $53.6 \%$ with $100 \%$ of heat recovery [30]. Heat loss to the environment was assumed to be $20 \%$ in this analysis. Pinch analysis was used to determine the maximum recoverable heat within the cycle, and where in the cycle the recovered heat can be used efficiently [31]. It was shown that a major part of the potential heat recovery can be achieved by cooling and solidifying molten copper(I) chloride exiting the oxygen reactor which is step 4 of the $\mathrm{Cu}-\mathrm{Cl}$ cycle. A direct contact heat exchanger for recovering heat from molten $\mathrm{CuCl}$ was proposed by Jaber [32], who evaluated the convective heat transfer between molten $\mathrm{CuCl}$ droplets in a counter-current spray flow.

Various options for heat recovery from molten $\mathrm{CuCl}$ were examined previously, including atomization with steam generation, casting/extrusion, drum flaker and a rotary spinning atomizer [33]. A casting/extrusion method was found to be the most efficient and reliable method for heat recovery from molten $\mathrm{CuCl}$. Modeling of solidification during a casting process has been investigated by many authors [34-38]. Most assume that conduction heat transfer is the main transport mechanism, and convective heat transfer from the molten metal to the solid shell is not considered. A number of studies have been reported to predict solidification of liquids flowing through pipes [39-41]. Sampson et al. [42] developed a mathematical model for solidification of a liquid metal with a low Prandtl number, flowing through a pipe maintained at a subfreezing temperature. Conde et al. [43] presented and solved a two-dimensional model with the commercial software FLUENT to analyze the freezing of water and other liquids in tubes under laminar conditions. Those authors validated their model with experimental results of blocking lengths, provided earlier by Cheung [44]. Most of the previous studies assumed a constant wall temperature. 
Recently, Seeniraj and Hari [45] studied the transient freezing of warm liquids flowing through convectively cooled pipes under laminar and turbulent flow conditions. In the limiting case, the results agreed with those reported earlier for steady state and constant temperature boundary conditions.

The objective of this research is to analyze the casting/extrusion method for heat recovery from molten $\mathrm{CuCl}$ in the $\mathrm{Cu}-\mathrm{Cl}$ cycle. The system is similar to a counterflow heat exchanger. The molten material flows inside the tube, and the coolant flows through the annulus. As the molten material cools, its phase changes from liquid to solid. Solidification heat transfer from the molten material is investigated through modeling of the system. Both laminar and turbulent flow conditions are studied. The coolant can be a single phase fluid (e.g. air) or a two-phase fluid (e.g. water/steam), but the focus here is on the former configuration. The aim is to provide useful data to design a heat exchanger for recovering heat from molten copper(I) chloride.

\section{HEAT RECOVERY ANALYSIS IN THE COPPER-CHLORINE CYCLE}

Based on a hydrogen production rate of $3 \mathrm{~kg} /$ day, the heat flow distribution in the $\mathrm{Cu}-\mathrm{Cl}$ cycle is calculated and presented in Table 4. The total heat requirement of the cycle is $8.16 \mathrm{~kW}$ while 1.48 $\mathrm{kW}$ of heat can be recovered within the cycle through cooling of $\mathrm{HCl}, \mathrm{O}_{2}$, and $\mathrm{CuCl}$. About $88 \%$ of the total heat recovery can be achieved by cooling and solidifying of molten $\mathrm{CuCl}$ which can improve the overall efficiency of the copper-chlorine cycle accordingly. Table 5 shows the effect of heat recovery on the overall efficiency of the cycle. The electrical energy required for the electrolysis step is $62.6 \mathrm{~kJ} / \mathrm{mol} \mathrm{H}_{2}$ which is equal to $1.08 \mathrm{~kW}$ for a hydrogen production rate of 3 $\mathrm{kg} /$ day. Heat loss of $20 \%$ to the environment is considered in the analysis. The efficiency of the cycle is calculated based on the higher heating value of hydrogen. The overall efficiency of the cycle is improved from $45 \%$ when there is no heat recovery, to $51 \%$ when $80 \%$ of released heat is recovered within the cycle.

A schematic of an indirect contact heat recovery system for molten $\mathrm{CuCl}$ is shown in Fig. 1. Hot liquid (i.e. molten $\mathrm{CuCl}$ ) enters the pipe at $\mathrm{z}=0$ with a uniform temperature $T_{\text {in }}$, which is greater 
than the freezing temperature of the liquid, $T_{f}$. A coolant at temperature $T_{c}<T_{t}$ flows in the shell side, counter-currently. The convection heat transfer coefficient of the coolant is assumed to be constant.

The analysis has two steps. Firstly, solidification of a hot liquid flowing in a tube, subjected to an air flow with constant temperature, is modeled. Afterwards, a double-pipe heat exchanger, in which air flows through the outer tube, is investigated.

To model solidification of molten $\mathrm{CuCl}$ in a tube, an instantaneous energy balance is applied to a differential element:

$-\left[\rho u_{i n}\left(\pi r_{i}^{2}\right)\right] c_{p_{l}}\left(\mathrm{~d} T_{b}\right)=h_{i}\left(2 \pi r_{f} \mathrm{dz}\right)\left(T_{b}-T_{f}\right)$

The enthalpy change of the flowing liquid is equal to the convective heat transfer from the liquid to the growing solid layer. By introducing the following non-dimensional variables,

$\mathrm{Z}=\frac{\mathrm{Z}}{r_{i}}$

$\theta_{b}=\frac{T_{b}-T_{f}}{T_{\text {in }}-T_{f}}$

the energy balance becomes

$P e \frac{\partial \theta_{b}}{\partial Z}+2 N u_{i} \theta_{b}=0$

where 
$N u=\frac{2 h_{i} r_{f}}{k_{l}}$

At the solid-liquid interface, the sum of the heat released due to solidification, and the heat flux from the hot liquid to the solidified layer, is equal to the heat flux conducted through the solid layer, i.e.,

$-\rho_{s} \frac{\partial r_{f}}{\partial t} L+h_{i}\left(T_{b}-T_{f}\right)=k_{s}\left(\frac{\partial T_{s}}{\partial r}\right)_{r=r_{f}}$

By introducing non-dimensional variables and parameters,

$R=\frac{r}{r_{i}}$

$T=\frac{\alpha_{s} t}{r_{i}^{2}}$

$\mathrm{Ste}_{s}=\frac{\left(T_{f}-T_{c}\right) \mathrm{c}_{p_{s}}}{L}$

Ste $_{l}=\frac{\left(T_{\text {in }}-T_{f}\right) \mathrm{c}_{p_{l}}}{L}$ 
$\theta_{s}=\frac{T_{f}-T_{s}}{T_{f}-T_{c}}$

the non-dimensional form of Eq. (8) becomes

$\frac{\partial R_{f}}{\partial T}=-S t e_{s}\left(\frac{\partial \theta_{s}}{\partial R}\right)_{R=R_{f}}+\left(\frac{\phi \theta_{b}}{R_{f}}\right)$

where

$\phi=0.5\left(\frac{C_{p}}{k}\right)_{s l} S_{s t} N u_{i}$

Heat conduction in the solid layer can be considered in the axial $(z)$ and radial $(r)$ directions. However, since the solid bulk transport in the axial direction is more significant than heat conduction in the same direction, the $z$-term of the equation is negligible with respect to the $r$-terms. Moreover, the axial growth of the solidified layer is much slower than the rate of change of temperature of the liquid with time. This allows the time derivative of temperature in the heat conduction equation to be neglected for the solid layer [45]. Therefore, the conduction equation in the solid layer is reduced to the following equation

$\frac{\partial^{2} T_{s}}{\partial r^{2}}+\frac{1}{r} \frac{\partial T_{s}}{\partial r}=0$

The boundary conditions are as follows

$T_{s}=T_{f}$ at $r=r_{f}$ 
$-k_{s} \frac{\partial T_{s}}{\partial r}=h_{0}\left(T_{s}-T_{c}\right)$ at $r=r_{i}$

The non-dimensional form of the equation and boundary conditions become

$\frac{\partial^{2} \theta_{s}}{\partial R^{2}}+\frac{1}{R} \frac{\partial \theta_{s}}{\partial R}=0$

$\theta_{s}=0$ at $R=R_{t}$

$\frac{\partial \theta_{s}}{\partial R}=B i\left(1-\theta_{s}\right)$ at $R=1$

where

$B i=\frac{h_{o} r_{i}}{k_{s}}$

Solving Eq. (19) subject to the boundary conditions, the temperature distribution in the solid layer is

$\theta_{s}=\left(\frac{B i}{1-B i \operatorname{Ln} R_{f}}\right) \operatorname{Ln}\left(\frac{R}{R_{f}}\right)$

The value of $\left(\partial \theta_{s} / \partial R\right)_{R=R_{f}}$ is obtained from Eq. (23) and substituted in Eq. (14), yielding

$R_{f}\left(\frac{\partial R_{f}}{\partial T}\right)=-S t e_{s}\left(\frac{B i}{1-B i \operatorname{Ln} R_{f}}\right)+\phi \theta_{b}$ 
Equations (4) and (24) form a set of coupled non-linear partial differential equations with the initial and boundary conditions as follows:

$\theta_{b}=1_{s}, R_{f}=1$ at $r=0, Z \geq 0$

$\theta_{b}=1$ at $Z=0, r \geq 0$

The solidification of the flowing hot liquid is possible only for a certain range of values of parameters. For solidification to begin, $\left(\partial \mathrm{R}_{\mathrm{f}} / \partial T\right.$ ) should be less than zero when $T$ approaches zero. Therefore, from Eq. (24),

$$
\left(\frac{\partial R_{f}}{\partial T}\right)_{T=0}=-S t e_{s} B i+\phi
$$

The condition for the commencement of solidification is

\section{$\mathrm{Bi} \mathrm{Ste}_{\mathrm{s}}>\varnothing$}

Here $\left.(\mathrm{Bi} \mathrm{Ste})_{s}\right)$ characterizes the amount of heat absorbed by the coolant and $\phi$ indicates heat transfer from the hot liquid by convection. Solidification would begin only when the heat extracted by the coolant is greater than the heat added by the liquid flowing in the pipe. Using Eq. (15), the limiting condition for solidification becomes

Bi Ste ${ }_{S l}>0.5\left(\frac{C_{p}}{k}\right)_{\text {sl }} N u_{i}$

For a laminar, fully developed flow with a constant surface temperature, the Nusselt number is constant [46]: 
The spatial distribution of the bulk mean temperature can be found by integrating Eq. (4) with respect to $Z$ :

$\theta_{b}=\exp \left(\frac{-7.32}{P e} \mathrm{Z}\right)$

Substituting Eq. (31) into (24) yields

$R_{f}\left(\frac{\partial R_{f}}{\partial T}\right)=-S t e_{s}\left(\frac{B i}{1-B i \operatorname{Ln} R_{f}}\right)+\phi \exp \left(\frac{-7.32}{P e} Z\right)$

The thickness of the solid layer reaches a steady state when the heat flux from the hot liquid at the interface is equal to heat transfer to the coolant by convection. By replacing $\partial R_{f} / \partial T=0$, Eq. (32) becomes

$-\operatorname{Ste}_{s}\left(\frac{B i}{1-B i \operatorname{Ln} R_{f}}\right)+\phi \exp \left(\frac{-7.32}{P e} Z\right)=0$

Therefore,

$R_{f}=\exp \left[\frac{1}{B i}-\frac{S t e_{s}}{\phi} \exp \left(\frac{7.32}{P e} Z\right)\right]$

In the case of turbulent flow, the correlation proposed by Gnielinski [47] is modified to find the Nusselt number as a function of $R_{f}$ as follows: 
$\mathrm{Nu}_{\mathrm{i}}=0.012\left[\left(\frac{R e}{R_{f}}\right)^{0.87}-280\right] P^{0.4}$

This correlation is valid over the following range of conditions:

\section{$1.5 \leq \operatorname{Pr} \leq 500,3 \times 10^{3} \leq \operatorname{Re} \leq 10^{6}$}

The Nusselt number obtained from Eq. (35) is substituted into Eqs. (4) and (24). Each equation is then discretized using forward difference approximations with a constant step size. The effect of the step size on the results is investigated. The optimum step sizes for $t$ and $z$ are found to be 0.01 and 0.001, respectively. Further reduction of the step sizes by a factor of 2 will cause up to $1 \%$ change in the results.

In the next step of the analysis, a counter-current flow in the outer tube is also considered and added to the model. For fully developed laminar flow in the tube annulus, assuming one surface is insulated and the other is held at a constant temperature, the Nusselt number is obtained from tabulated data [46]. An energy balance is applied to a differential element of the fluid:

$$
\dot{m}_{c} C_{p_{c}} \mathrm{~d} T_{c}=-h_{c}\left(2 \pi r_{i} \mathrm{dz}\right)\left(T_{w}-T_{c}\right)
$$

In each step of the calculation, $T_{c}$ is updated using Eq. (37). Equations (4) and (24) are solved simultaneously as described above.

\section{RESULTS AND DISCUSSION}

The computed results are compared with past results reported by Seeniraj and Hari [45] for selected values of parameters. The coolant temperature is assumed to be constant. Figures 2 and 3 show the axial variation of the bulk mean temperature and axial growth of the solid layer for laminar flow, 
respectively. In these figures, $B i=10$, Ste $_{S} / S t e_{l}=0.5$, and $T=0.5$. Figures 4 and 5 compare the present work with the results obtained by Seeniraj and Hari [45] for turbulent flow. Our results show good agreement with the data presented by Seeniraj and Hari. Comparing the laminar and turbulent flows shows that the solid layer grows much faster in turbulent flow, mainly due to a larger convection heat transfer coefficient. This also affects the liquid bulk mean temperature. The variation of the bulk temperature along the tube is more significant for turbulent flow.

An experimental setup was established at the University of Ontario Institute of Technology for investigation of the solidification of molten $\mathrm{CuCl}$ in a double-pipe heat exchanger. The diameter of the inner tube is $20 \mathrm{~cm}$ and the outer tube diameter is $25 \mathrm{~cm}$. The mass flow rate of molten $\mathrm{CuCl}$ is $4.17 \mathrm{~g} / \mathrm{s}$. In this section, air is considered as a coolant in counter-current flow. The inlet temperature of air is $25^{\circ} \mathrm{C}$. $\mathrm{CuCl}$ properties at the melting point $\left(420^{\circ} \mathrm{C}\right)$ are used for both solid and liquid phases.

Figure 6 shows the variation of the air temperature along the tube. The mass flow rate of air is $3 \mathrm{~g} / \mathrm{s}$. The heat extracted from solidifying $\mathrm{CuCl}$ causes an increase in air temperature from $25^{\circ} \mathrm{C}$ to $190^{\circ} \mathrm{C}$ in a heat recovery system with a length of $15 \mathrm{~cm}$. The effect of the inner tube radius on the air temperature and the length of the heat recovery system is also shown in Figure 6. While the outer tube radius is fixed, raising the inner tube radius causes an increase in the air temperature. This occurs because the flow in the shell is laminar, and hence the Nusselt number is almost constant. Therefore, increasing the inner tube radius causes a decrease in the hydraulic diameter which increases the convection heat transfer coefficient in the shell. An increase in the heat transfer rate results in a higher coolant temperature. Therefore, the outlet temperature of the coolant and the length of the heat exchanger are increased significantly by increasing the inner tube radius. The length of the heat recovery system is $29 \mathrm{~cm}$ and $53 \mathrm{~cm}$ for the inner tube radius of $11 \mathrm{~cm}$ and $12 \mathrm{~cm}$, respectively. The outlet temperature of air is $255{ }^{\circ} \mathrm{C}$ and $370{ }^{\circ} \mathrm{C}$ for the inner tube radius of $11 \mathrm{~cm}$ and $12 \mathrm{~cm}$, respectively. As a result, the heat transfer from the molten salt rises. 
Increasing the inner tube radius also affects the growth of solid layer. This is illustrated in Fig. 7. For a heat recovery system with an inner tube radius of $10 \mathrm{~cm}$, the length of the system is not sufficient to solidify the entire molten salt flowing in the tube. Therefore, as discussed earlier, it is required to increase the inner tube radius and the length of the system to achieve an efficient heat recovery from molten salt. This is also observed in Fig. 7.

For a heat recovery system with an inner tube radius of $12 \mathrm{~cm}$, the effect of mass flow rate is investigated. Figure 8 demonstrates the variation of the inner wall temperature along the tube. A heat recovery system with a higher air flow rate has a higher heat transfer rate and hence, a longer length. The length of the system is $54 \mathrm{~cm}$ and $91 \mathrm{~cm}$ for an air flow rate of $3 \mathrm{~g} / \mathrm{s}$ and $4 \mathrm{~g} / \mathrm{s}$, respectively. Since the wall temperature at the top and bottom of the heat recovery system is almost the same for two air flow rates, the variation of wall temperature along the tube is slower for the longer tube.

The heat flux along the heat recovery system is shown in Fig. 9. As shown in Figs. 6 and 8, both wall and air temperatures rise when increasing the air flow rate. However, the temperature difference, $\left(T_{w}-T_{c}\right)$ is the same for different air flow rates. Therefore, the heat flux along the heat recovery system is similar for both air flow rates. However, since the length of the heat recovery system is longer for a higher air flow rate, the total heat transfer rate from molten salt over the system is greater for a greater air flow rate. The results presented in this section provide useful data which can assist efforts to design a system for recovering heat from molten copper(I) chloride in the Cu-Cl cycle.

\section{CONCLUSIONS}

The present investigation of solidification of a hot liquid flowing through a tube, which is cooled convectively, has yielded several results that improve our understanding of molten $\mathrm{CuCl}$ heat recovery. Variations of the liquid bulk mean temperature are evaluated by applying an energy balance to a differential element of the liquid. The growth of a solid layer along the tube is obtained by establishing an energy balance at the solid-liquid interface. The conduction equation is solved in 
the solid layer to determine the radial distribution of the solid. The results are validated against past data available in literature. A double-pipe heat exchanger (casting/extrusion method) is investigated for recovering heat from the molten $\mathrm{CuCl}$ in the $\mathrm{Cu}-\mathrm{Cl}$ thermochemical cycle for hydrogen production. Counter-current air flow is considered as a coolant. The results for axial growth of the solid layer, and variations of the coolant and wall temperatures, have been presented. It has been shown that reducing the inner tube diameter increases the heat exchanger length and increases the outlet temperature of air significantly. Also, increasing the mass flow rate of air increases the total heat flux from the molten salt by increasing the length of the heat exchanger. The results in this paper provide useful data which can assist efforts to design a heat exchanger for recovering heat from molten copper(I) chloride.

\section{Acknowledgement}

Support of this research from the Natural Sciences and Engineering Research Council of Canada (NSERC) and Atomic Energy of Canada Limited (AECL) is gratefully acknowledged.

\section{NOMENCLATURE}

\section{$\mathrm{Bi} \quad$ Biot number}

$C_{p} \quad$ specific heat at constant pressure, $\mathrm{J} / \mathrm{kgK}$

$h \quad$ convection heat transfer coefficient, $\mathrm{W} / \mathrm{m}^{2} \mathrm{~K}$

$k \quad$ thermal conductivity, $\mathrm{W} / \mathrm{mK}$

$\mathrm{Nu} \quad$ Nusselt number

$\mathrm{Pe} \quad$ Peclet number

$R \quad$ non-dimensional radial coordinate

$\mathrm{Re} \quad$ Reynolds number

$r \quad$ radial coordinate, $\mathrm{m}$

Ste Stefan number

$\mathrm{T}$ temperature, ${ }^{\circ} \mathrm{C}$

$u \quad$ velocity, $\mathrm{m} / \mathrm{s}$

Z non-dimensional axial coordinate

$\mathrm{Z}$ axial coordinate, $\mathrm{m}$

\section{Greek Letters}

$\theta$ non-dimensional temperature

$\mu \quad$ viscosity, Pa.s

$\rho$ density, $\mathrm{kg} / \mathrm{m}^{3}$

$I$ non-dimensional time

\section{Subscripts}

b bulk

c coolant

$f \quad$ freezing 


$\begin{array}{ll}i & \text { inner } \\ \text { in } & \text { inlet } \\ l & \text { liquid } \\ o & \text { outer } \\ s & \text { solid } \\ w & \text { wall }\end{array}$

\section{REFERENCES}

[1] Nersesian R. L. Energy for the $21^{\text {st }}$ Century: A Comprehensive Guide to Conventional and Alternative Sources. New York: M. E. Sharpe, 2010.

[2] Dell R. Clean Energy. London: Royal Society of Chemistry, 2004.

[3] Kothari R., Buddhi D., Sawhney R. L. Comparison of Environmental and Economic Aspects of Various Hydrogen Production Methods. Renewable and Sustainable Energy Reviews. 2008; 12: 553-563.

[4] Kim J. H., Um D. H., Kwon O. C. Hydrogen Production from Burning and Reforming of Ammonia in a Microreforming System. Energy Conversion and Management. 2012; 56: 184-191.

[5] Kirtay E. Recent Advances in Production of Hydrogen from Biomass. Energy Conversion and Management. 2011; 52: 1778-1789.

[6] Borgognoni F., Tosti S., Vadrucci M., Santucci A. Combined Methane and Ethanol Reforming for Pure Hydrogen Production through Pd-based Membranes. International Journal of Hydrogen Energy. Pro2013; 38: 1430-1438.

[7] Jing D., Liu H., Zhang X., Zhao L., Guo L. Photocatalytic Hydrogen Production Under Direct Solar Light in a CPC Based Solar Reactor: Reactor Design and Preliminary Results. Energy Conversion and Management. 2009; 50: 2919-2926.

[8] Yan Q., Guo L., Lu Y., Thermodynamic Analysis of Hydrogen Production from Biomass Gasification in Supercritical Water. Energy Conversion and Management. 2006; 47: 1515-1528.

[9] Ni M. 2D Heat and Mass Transfer Modelling of Methane Steam Reforming for Hydrogen Production in a Compact Reformer. Energy Conversion and Management. 2013; 65: 155-163.

[10] Spath P. L. and Mann M. K. Life Cycle Assessment of Hydrogen Production via Natural Gas Steam Reforming. Technical Report. NREL/TP-570-27637. 2001.

[11] Tinoco R. R., Mansilla C., Bouallou C. Competitiveness of Hydrogen Production by High Temperature Electrolysis: Impact, of the Heat Source and Identification of Key Parameters to Achieve Low duction Costs. Energy Conversion and Management. 2010; 51: 2623-2634.

[12] Atlam O. And Kolhe M. Equivalent Electrical Model for a Proton Exchange Membrane (PEM) Electrolyser. Energy Conversion and Management. 2010; 52: 2952-2957.

[13] Menon V., Janardhanan V. M., Deutschmann O. A Mathematical Model to Analyze Solid Oxide Electrolyzers Cells (SOECs) for Hydrogen Production. Chemical Engineering Science. In Press. 2013. 
[14] Ferrero D., Lanzini A., Santarelli M., Leone P. A Comparative Assessment of Hydrogen Production from Low- and High-temperature Electrolysis. International Journal of Hydrogen Energy. 2013; 38: 3523-3536.

[15] Ni M., Leung M. K., Leung D. Y. Energy and Exergy Analysis of Hydrogen Production by a Proton Exchange Membrane (PEM) Electrolyzer. Energy Conversion and Management. 2008; 49: 2748-2756.

[16] Bhandari R., Trudewind C. A., Zapp P., Life Cycle Assessment of Hydrogen Production via Electrolysis. Journal of Cleaner Production. In press. 2013.

[17] Schultz K. Thermochemical Production of Hydrogen from Solar and Nuclear Energy. Presentation to the Stanford Global Climate and Energy Project, General Atomics, San Diego, CA, 2003.

[18] Vitart X., Duigou A. L., Carles P. Hydrogen Production Using the Sulfur-iodine Cycle Coupled to a VHTR: An Overview. Energy Conversion and Management. 2006; 47: 2740-2747.

[19] Funk J. E. Thermochemical Hydrogen Production: Past and Present. International Journal of Hydrogen Energy 2001; 26: 185-190.

[20] Steinfeld A. Solar Hydrogen Production via a Two-step Water Splitting Thermochemical Cycle Based on Zn/ZnO Redox Reactions. International Journal of Hydrogen Energy. 2002; 27: 611-619.

[21] Huang C. and Raissi A. T. Analysis of Sulfur Iodine Thermochemical Cycle for Solar Hydrogen Production. Part I: Decomposition of Sulfuric Acid. Solar Energy. 2005; 78: 632-646.

[22] Xinxin W. and Kaoru O. Thermochemical Water Splitting for Hydrogen Production Utilizing Nuclear Heat from an HTGR. Tsinghua Science and Technology. 2005; 10: 270-276.

[23] Abanades S., Charvin P., Lemont F., Flamant G. Novel Two-step $\mathrm{SnO}_{2} / \mathrm{SnO}_{\text {Water-splitting }}$ Cycle for Solar Thermochemical Production of Hydrogen. International Journal of Hydrogen Energy. 2008; 33: 6021-6030.

[24] Galvez M. E., Frei A., Albisetti G., Lunardi G., Steinfeld A. Solar Hydrogen Production via a Two-step Thermochemical Process Based on MgO/Mg Redox Reactions-Thermodynamic and Kinetic Analyses. International Journal of Hydrogen Energy. 2008; 33: 2880-2890.

[25] Rosen M. A. Advances in Hydrogen Production by Thermochemical Water Decomposition: A Review. Energy-The International Journal. 2010; 35: 1068-1076.

[26] Charvin P., Stephane A., Florent L., Gilles F. Analysis of Solar Chemical Processes for Hydrogen Production from Water Splitting Thermochemical Cycles. Energy Conversion and Management. 2008; 49: 1547-1556.

[27] Ghandehariun S., Naterer G. F., Dincer I., Rosen M. A. Solar Thermochemical Plant Analysis for Hydrogen Production with the Copper-chlorine Cycle. International Journal of Hydrogen Energy. 2010; 35: 8511-8520. 
[28] Lewis M. A. and Sink C. High Temperature Thermochemical Processes. DOE Hydrogen Program, Annual Progress Report. 2008; 240-244.

[29] Naterer G. F., Gabriel K., Wang Z. L., Daggupati V. N., Gravelsins R. Thermochemical Hydrogen Production with a Copper-chlorine Cycle. I: Oxygen Release from Copper Oxychloride Decomposition. International Journal of Hydrogen Energy. 2008; 33: 5439-5450.

[30] Wang Z. L., Naterer, G. F., Gabriel K. S., Gravelsins R., Daggupati, V. N. Comparison of Sulfur-iodine and Copper-chlorine thermochemical hydrogen production cycles. International Journal of Hydrogen Energy. 2010; 35: 4820-4830.

[31] Ghandehariun S., Rosen, M. A., Naterer, G. F., Wang Z. Pinch Analysis for Recycling Thermal Energy in the Cu-Cl Cycle. International Journal of Hydrogen Energy. 2012; 37: 16535-16541.

[32] Jaber O., Naterer G. F., Dincer I. Heat Recovery from Molten $\mathrm{CuCl}$ in the Cu-Cl Cycle of Hydrogen Produuction. International Journal of Hydrogen Energy. 2010; 35: 6140-6151.

[33] Ghandehariun S., Rosen M. A., Naterer G. F., Wang Z. Comparison of Molten Salt Heat Recovery Options in the Cu-Cl Cycle of Hydrogen Production. International Journal of Hydrogen Energy. 2011; 36: 11328-11337.

[34] Lally B., Biegler L., Henein H. Finite Difference Heat Transfer Modeling for Continuous Casting. Metallurgical Transactions B. 1990; 21: 761-770.

[35] Tieu A. K. and Kim I. S. Simulation of the Continuous Casting Process by a Mathematical Model. International Journal of Mechanical Sciences. 1997; 39: 185-192.

[36] Das S. K. Thermal Modelling of DC Continuous Casting including Submould Boiling Heat Transfer. Applied Thermal Engineering. 1999; 19: 897-916.

[37] Tieu A. K. and Kim I. S. Heat Transfer Analysis for the Continuous Casting Process by the Front Tracking BEM. Engineering Analysis with Boundary Elements: 2000; 24: 215-223.

[38] Mahmoudi J. Mathematical Modelling of Fluid Flow, Heat Transfer and Solidification in a Strip Continuous Casting Process. International Journal of Cast Metals Research. 2006; 19: 223236.

[39] Wei S. S. and Guceri S. I. Solidification in Developing Pipe Flows. International Journal of Heat and Fluid Flow. 1987; 9: 225-232.

[40] Hwang G. J. and Tsai C. W. Effect of Natural Convection on Laminar Pipe Flow Solidification. International Journal of Heat and Mass Transfer. 1995; 38: 2733-2742.

[41] Gammon J. and Howarth J. A. The Inward Solidification of Cylinders with a Slightly Perturbed Temperature Distribution at the Boundary. International Communications in Heat and Mass Transfer. 1996; 23: 387-396.

[42] Sampson P. and Gibson R. D. Solidification of a Liquid Metal Following through a Circular Pipe: A Prediction of a Nozzle Blockage. Adv. Eng. Software. 1981; 3: 17-25. 
[43] Conde R., Parra M. T., Castro F., Villafruela J. M., Rodriguez M. A., Mendez C. Numerical Model for Two-phase Solidification Problem in a Pipe. Applied Thermal Engineering. 2004; 24: 2501-2509.

[44] Cheung F. B. and Baker L. Transient freezing of Liquids in Tube Flow. Nuclear Science and Engineering. 1976; 60: 1-9.

[45] Seeniraj R. V. and Hari G. S. Transient Freezing of Liquids in Forced Flow Inside Convectively Cooled Tubes. International Communications in Heat and Mass Transfer. 2008; 35: 786-792.

[46] Incropera F. P. and D. P. DeWitt. Fundamentals of Heat and Mass Transfer. New Jersey: John Wiley \& Sons, 2001.

[47] Rohsenow W., Hartnett J., Cho Y. Handbook of Heat Transfer. New York: McGraw-Hill Professional, 1998. 
Table 1. General hydrogen production methods.

\begin{tabular}{|l|l|l|}
\hline Method & Material resources & Energy supply \\
\hline Water electrolysis & Water & Electrical \\
\hline Thermochemical water splitting & Water & Thermal \\
\hline Gasification & Water, fossil fuels, biomass & Thermal \\
\hline Reforming & Water, fossil or biofuels & Thermal \\
\hline Photocatalysis & Water & Photonic \\
\hline Biophotolysis & Water & Photonic, biochemical \\
\hline
\end{tabular}

Table 2. Typical specifications of various types of electrolyzers.

\begin{tabular}{|l|l|l|l|l|}
\hline Specification & Unit & Alkaline & PEM & SOE \\
\hline Technology maturity & & State of the art & Demonstration & R \& D \\
\hline Cell temperature & ${ }^{\circ} \mathrm{C}$ & $60-80$ & $50-80$ & $900-1000$ \\
\hline Cell pressure & $\mathrm{bar}$ & $<30$ & $<30$ & $<30$ \\
\hline Current density & $\mathrm{A} / \mathrm{cm}^{2}$ & $0.2-0.4$ & $0.6-2.0$ & $0.3-1.0$ \\
\hline Cell voltage & $\mathrm{V}$ & $1.8-2.4$ & $1.8-2.2$ & $0.95-1.3$ \\
\hline System specific energy consumption & $\mathrm{kWh} / \mathrm{Nm}^{3}$ & $4.5-7.0$ & $4.5-7.5$ & $2.5-3.5$ \\
\hline System hydrogen production & $\mathrm{Nm}^{3} / \mathrm{hr}^{2}$ & $<760$ & $<30$ & - \\
\hline System lifetime & year & $20-30$ & $10-20$ & - \\
\hline
\end{tabular}

Table3. Reaction steps in the Cu-Cl cycle.

\begin{tabular}{|l|l|c|}
\hline Step & \multicolumn{1}{|c|}{ Reaction } & Temperature Range $\left({ }^{\circ} \mathrm{C}\right)$ \\
\hline 1 & $2 \mathrm{CuCl}^{\circ}(\mathrm{aq})+2 \mathrm{HCl}(\mathrm{aq}) \rightarrow \mathrm{H}_{2}(\mathrm{~g})+2 \mathrm{CuCl}_{2}(\mathrm{aq})$ & $<100$ \\
\hline 2 & $\mathrm{CuCl}_{2}(\mathrm{aq}) \rightarrow \mathrm{CuCl}_{2}(\mathrm{~s})$ & $<100$ \\
\hline 3 & $2 \mathrm{CuCl}_{2}(\mathrm{~s})+\mathrm{H}_{2} \mathrm{O}(\mathrm{g}) \rightarrow \mathrm{Cu}_{2} \mathrm{OCl}_{2}(\mathrm{~s})+2 \mathrm{HCl}(\mathrm{g})$ & 400 \\
\hline 4 & $\mathrm{Cu}_{2} \mathrm{OCl}_{2}(\mathrm{~s}) \rightarrow 2 \mathrm{CuCl}(0)+1 / 2 \mathrm{O}_{2}(\mathrm{~g})$ & 500 \\
\hline
\end{tabular}

Table 4. Heat distribution in the $\mathrm{Cu}-\mathrm{Cl}$ cycle.

\begin{tabular}{|l|l|l|l|l|}
\hline Step & $\begin{array}{l}\text { Heat Requirement } \\
(\mathrm{kW})\end{array}$ & Endothermic Process & $\begin{array}{l}\text { Hear Recovery } \\
(\mathrm{kW})\end{array}$ & $\begin{array}{l}\text { Exothermic } \\
\text { Process }\end{array}$ \\
\hline 1 & 0 & - & 0 & - \\
\hline 2 & 2.12 & Drying & 0 & - \\
\hline 3 & 3.33 & $\begin{array}{l}\text { Heating } \mathrm{CuCl}_{2} \text {, generating superheated } \\
\text { steam, heat of reaction }\end{array}$ & 0.04 & $\mathrm{Cooling} \mathrm{HCl}$ \\
\hline 4 & 2.71 & Heating $\mathrm{Cu}_{2} \mathrm{OCl}_{2}$, heat of reaction & 0.14 & $\mathrm{Cooling} \mathrm{O}_{2}$ \\
\cline { 4 - 6 } & 8.16 & & 1.3 & Cooling CuCl \\
\hline Total & & 1.48 & \\
\hline
\end{tabular}

Table 5. Effect of heat recovery on the overall efficiency of the cycle

\begin{tabular}{|l|c|c|c|c|c|}
\hline Released heat recovered within the cycle (\%) & 0 & 20 & 50 & 80 & 100 \\
\hline Overall thermal efficiency (\%) & 45 & 46.5 & 49 & 51 & 53 \\
\hline
\end{tabular}




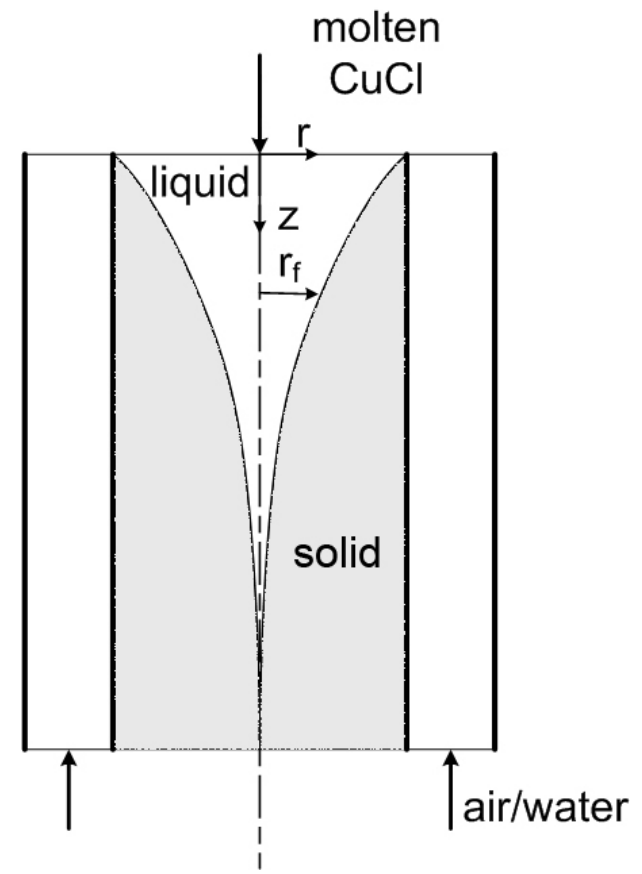

Fig. 1- Schematic of a counterflow heat exchanger with solidification.

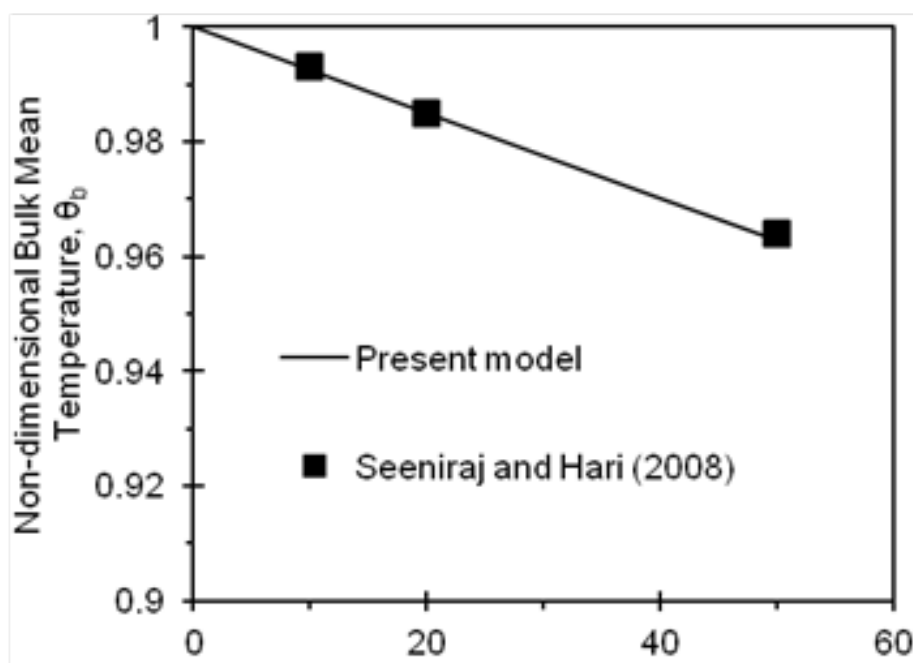

Non-dimensional Axial Coordinate , Z

Fig. 2- Axial variation of bulk mean temperature for laminar flow.

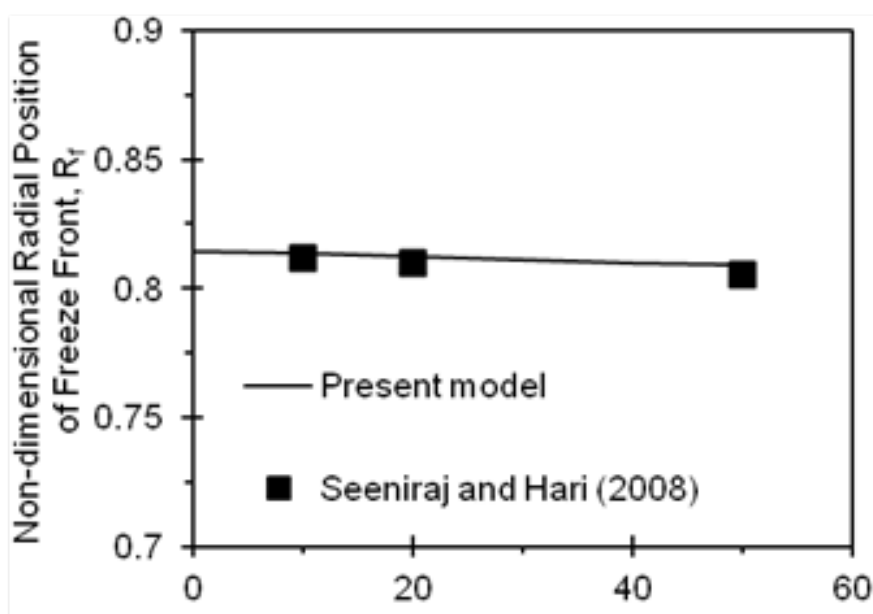

Non-dimensional Axial coordinate, $Z$

Fig. 3- Axial growth of solid layer for laminar flow. 


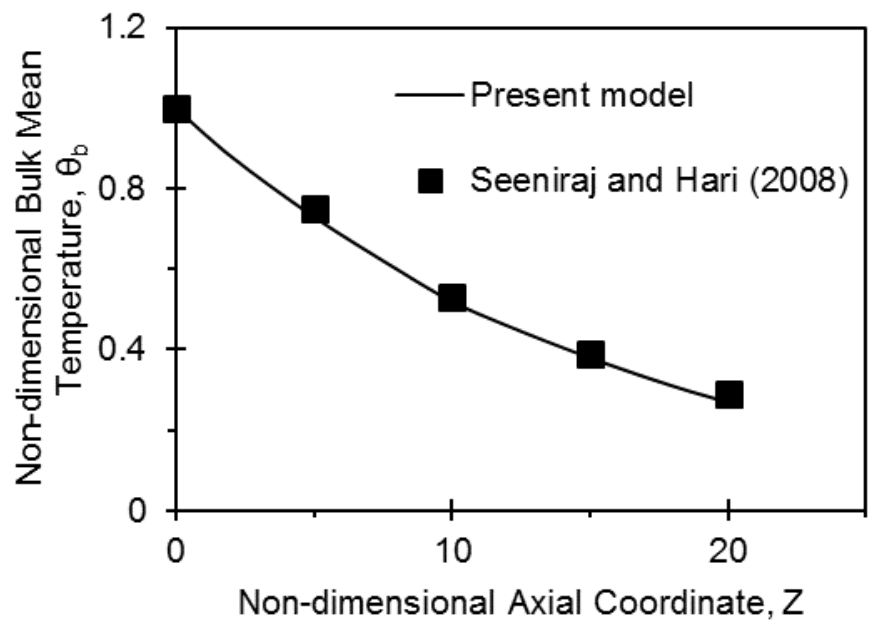

Fig. 4- Fluid bulk temperature variation along the tube for turbulent flow.

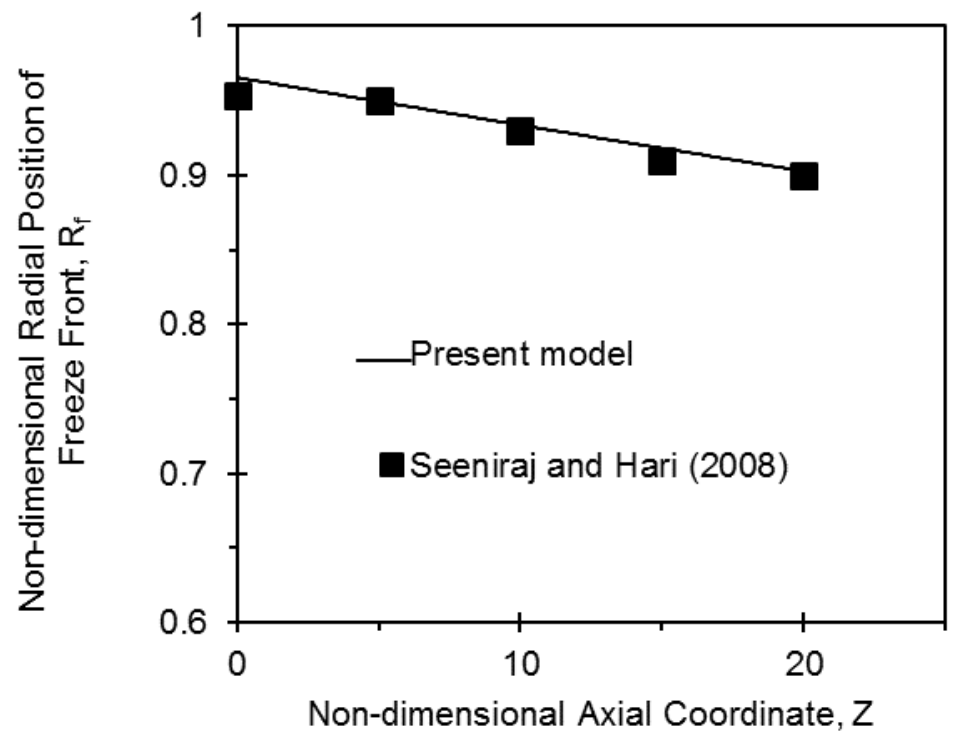

Fig. 5- Axial growth of solid layer for turbulent flow.

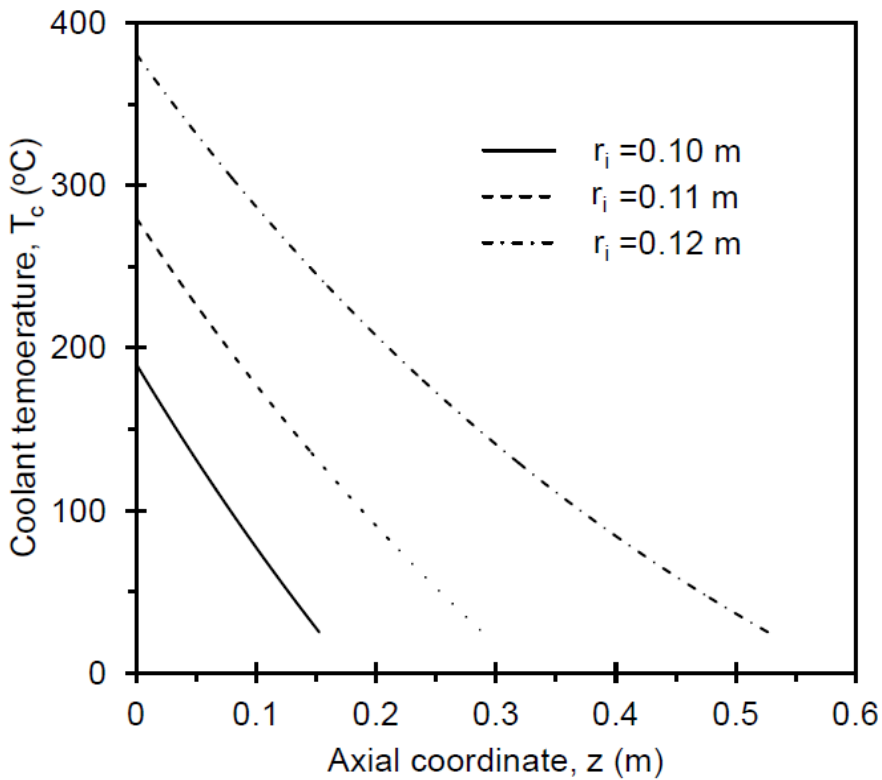

Fig. 6- Axial variation of the coolant temperature and effect of inner tube dimension. 


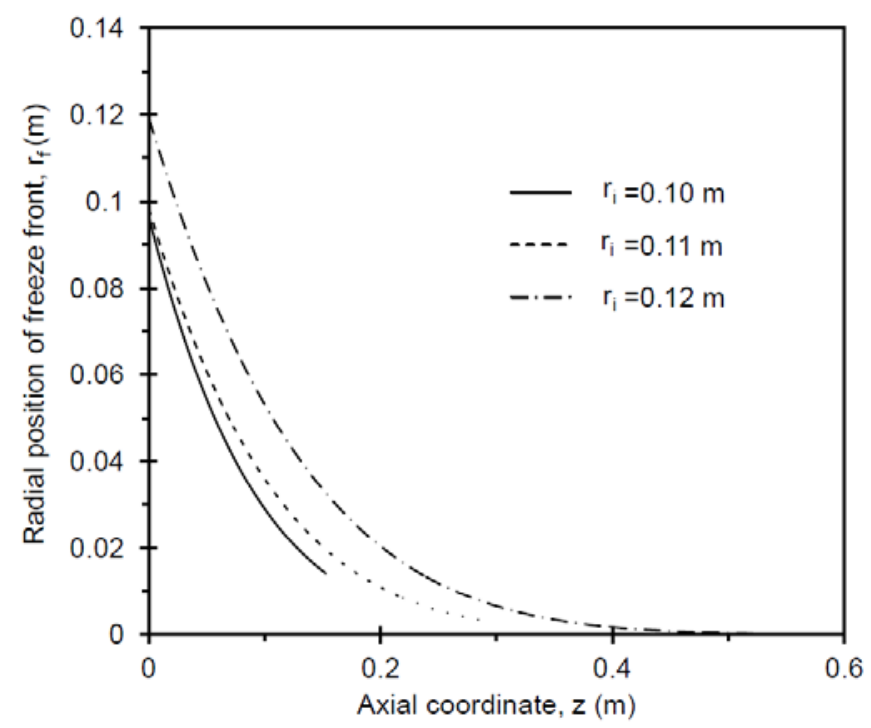

Fig. 7- Axial growth of solid layer for different inner tube radii.

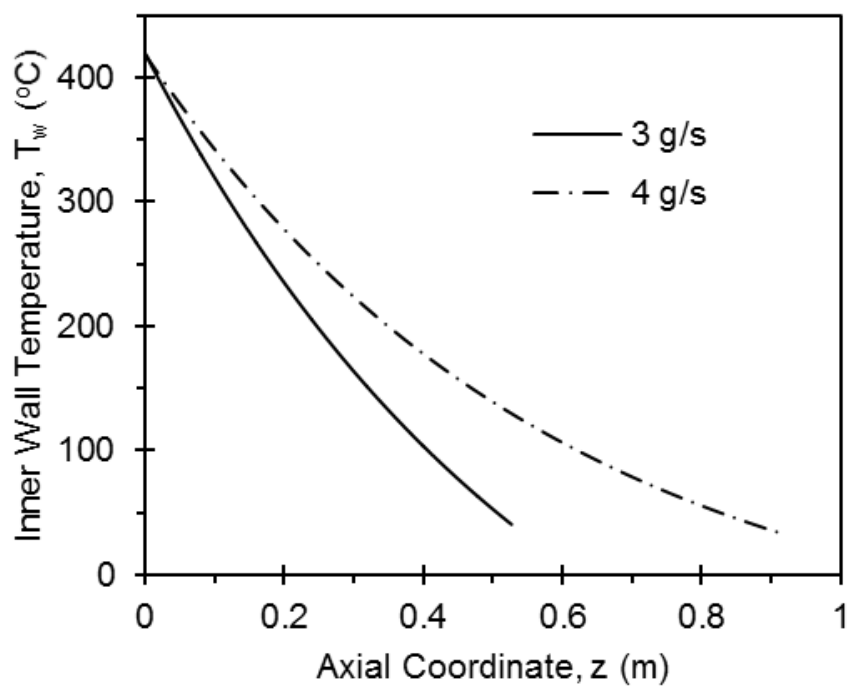

Fig. 8- Wall temperature variation along the tube for two different air flow rates.

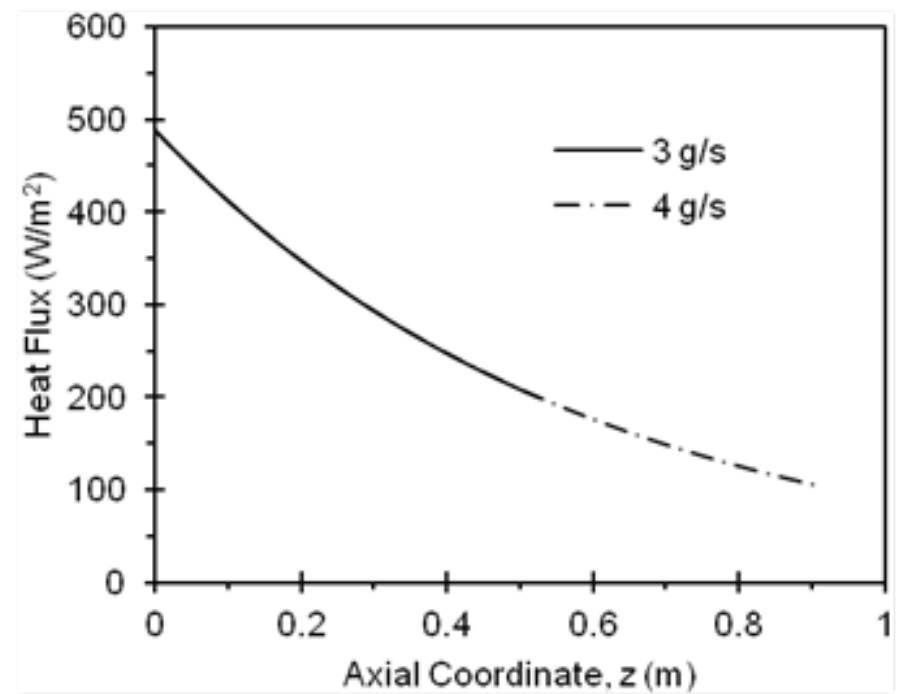

Fig. 9- Heat flux along the tube for two different air flow rates. 